\title{
The effect of deproteinization methods on the properties of glucosamine hydrochloride from shells of white leg shrimp (Litopenaeus vannamei) and black tiger shrimp (Penaeus monodon)
}

\section{Thuy Le Thi Minh ${ }^{1 *}$ Tran Thanh Truc $^{2}$ Kazufumi Osako ${ }^{3}$ CD}

${ }^{1}$ College of Aquaculture and Fisheries, Can Tho University (CTU), 94000, Can Tho, Vietnam. E-mail: 1tmthuy@ctu.edu.vn. "Corresponding author. ${ }^{2}$ College of Agriculture, Can Tho University (CTU), Can Tho, Vietnam.

${ }^{3}$ Department of Food Science and Technology, Tokyo University of Marine Science and Technology, Tokyo, Japan.

ABSTRACT: The effect of methods to remove protein content on the properties of glucosamine hydrochloride from the shells of white leg shrimp (Litopenaeus vannamei) and black tiger shrimp (Penaeus monodon) was investigated. Chitin from shrimp shells was obtained by demineralization in $6 \% \mathrm{HCl}$ for $12 \mathrm{~h}$, deproteinization by two different methods (first group soaked in $8 \% \mathrm{NaOH}$ for $36 \mathrm{~h}$ and second group treated in Alcalase enzyme at the concentration of $0.2 \%$ for 36h). Two group samples were converted to glucosamine hydrochloride by soaking in $36.76 \% \mathrm{HCl}$ solution for $5 \mathrm{~h}$ at $85{ }^{\circ} \mathrm{C}$. The results of fourier transform infrared spectroscopy (FTIR), solubility and recovery yield analysis showed that deproteinization methods did not significantly affect the properties of glucosamine hydrochloride. However, glucosamine hydrochloride from white leg shrimp shells contained higher recovery yield and solubility than black tiger shrimp shells. Key words: glucosamine hydrochloride, shrimp shells, deproteinization method, recovery yield, solubility.

Efeito de métodos de desproteinização nas propriedades do cloridrato de glucosamina de cascas de camarão de pernas brancas (Litopenaeus vannamei) e cascas de camarão de tigre preto (Penaeus monodon)

RESUMO: Investigou-se o efeito de métodos para remover o conteúdo de proteínas nas propriedades do cloridrato de glucosamina das conchas de camarão de pernas brancas (Litopenaeus vannamei) e camarão de tigre preto (Penaeus monodon). A quitina das cascas de camarão foi obtida por desmineralização em $\mathrm{HCl}$ a $6 \%$ por $12 \mathrm{~h}$, desproteinização por dois métodos diferentes (primeiro grupo embebido em NaOH a 8\% por 36 h e segundo grupo tratado na enzima Alcalase na concentração de 0,2\% por 36 h). Duas amostras de grupo foram convertidas em cloridrato de glucosamina por imersão em solução de $12 \mathrm{M} \mathrm{HCl}$ por $5 \mathrm{~h}$ a $85{ }^{\circ} \mathrm{C}$. Os resultados das análises de FTIR, solubilidade e rendimento de recuperação mostraram que os métodos de desproteinização não afetaram significativamente as propriedades do cloridrato de glucosamina. No entanto, o cloridrato de glucosamina de cascas de camarão de pernas brancas continha maior rendimento e solubilidade de recuperação do que as cascas de camarão tigre preto.

Palavras-chave: cloridrato de glucosamina, cascas de camarão de pernas brancas, cascas de camarão tigre preto, FTIR.

\section{INTRODUCTION}

White leg shrimp and black tiger shrimp have been the main products in exportation of Vietnam in recent years. According to Vietnam Association of Seafood Exporters and Producers (VASEP), the production of exported shrimp in the first six months in 2018 reached US \$1.6 billion, up $7.6 \%$ over the same period in 2017. However, during shrimp processing, a large amount of byproduct, such as heads, legs, shells, and tails, accounts for $40-50 \%$ of the total weight (XU et al., 2008). Utilization of shimp waste, including shrimp shells, is necessary from the viewpoints of both environmental conservation and the development of new valuable products such as chitin, chitosan and glucosamine hydrochloride.

Glucosamine is naturally present in the shells of shellfish, animal bones, bone marrow, and fungi. Glucosamine can be produced commercially in many different ways by the hydrolysis of crustacean exoskeletons or, less commonly, by fermentation of grain such as corn or wheat (SHAHIDI et al., 1999). Glucosamine in the form of glucosamine sulphate, glucosamine hydrochloride, or N-acetyl-glucosamine is extensively used as a dietary supplement in the treatment for osteoarthritis, knee pain, and back pain (HOUPT et al., 1999. LUO et al., 2005), and a critical evaluation indicated that glucosamine is safe under 
current conditions of use and does not affect glucose metabolism (ANDERSON et al., 2005).

Glucosamine hydrochloride (G-HCl) production from commercial chitin and chitosan (LEITE et al., 2002; LI et al., 2007), crustacean shells (BENAVENTE et al., 2015), crab exoskeletons (JORGE et al., 2019) has been characterized. However, little information is available regarding the effect of deproteinization methods on the properties of glucosamine hydrochloride from shrimp shells. Therefore, the purpose of this study was to produce $\mathrm{G}-\mathrm{HCl}$ by investigating the changes of G-HCl properties from shrimp shells by different deproteinization methods, i.e., alkaline method and enzyme method.

\section{MATERIALS AND METHODS}

\section{Preparation of shrimp shells}

White leg shrimp shells and black tiger shrimp shells were collected from a frozen seafood company in Can Tho city, Vietnam. The samples were transported to our laboratory under iced condition, washed with chilled water before being cut into small pieces by scissors, placed in polyethylene bags and then stored at $-20{ }^{\circ} \mathrm{C}$ until use.

\section{Chitin extraction}

Chitin was extracted from shrimp shells by demineralization in $6 \% \mathrm{HCl}$ (analytical grade, 36 - 38\%, Xilong Scientific Co., Ltd., Guangdong, China) for $12 \mathrm{~h}$ with gentle stirring at a sample $/ \mathrm{HCl}$ solution ratio of 1:10 (w/v) and deproteinization by two different methods (alkaline method by soaking in $8 \% \mathrm{NaOH}$ (analytical grade, $96.0 \%$, Guangdong Guanghua Sci-Tech Co., Ltd., Guangdong, China) for $36 \mathrm{~h}$ with continuous stirring at a sample $/ \mathrm{NaOH}$ solution ratio of 1:10 (w/v) and enzyme method by treating in $0.2 \%$ Alcalase enzyme $2.4 \mathrm{~T}$ (Novozymes, Denmark) for $36 \mathrm{~h}$ at $40{ }^{\circ} \mathrm{C}$. Two groups of chitin obtained were washed several times with distilled water until $\mathrm{pH}$ neutral and dried at $50{ }^{\circ} \mathrm{C}$ for $10 \mathrm{~h}$. Finally, chitin was milled and screened to select the fraction of particles with a size lower than $0.22 \mathrm{~mm}$.

\section{Glucosamine hydrochloride production}

Glucosamine hydrochloride production was performed following the method described by BENAVENTE et al. (2015) with minor modifications by reducing the dried time at $50{ }^{\circ} \mathrm{C}$ from $12 \mathrm{~h}$ to 10h. Chitin collected from two different methods of removing protein content was dissolved in $36.76 \%$ $\mathrm{HCl}$ at $85{ }^{\circ} \mathrm{C}$ for $5 \mathrm{~h}$ at a sample/ $\mathrm{HCl}$ solution ratio of 1:20 (w/v). After dissolving, the coarse solids were removed by filtration, and the collected solution was left to crystallize by adding ethyl alcohol $(15 \mathrm{~mL}, \mathrm{w}=$ $95 \%$ ), and kept at $4{ }^{\circ} \mathrm{C}$ for 15 days. The mixture was once more filtered, and the solid crystals were washed with ethyl alcohol and dried at $50{ }^{\circ} \mathrm{C}$ for $10 \mathrm{~h}$.

\section{Determination of moisture, protein and ash content} Moisture, ash and protein content in the shrimp shells after demineralization and deproteinization were analyzed according to the Association of Official Analytical Chemists methods (AOAC 2000). The moisture content was determined by drying the samples in an air oven at $105{ }^{\circ} \mathrm{C}$ for $24 \mathrm{~h}$ until constant weights were obtained, cooled in a desiccator and re-weighed. The difference between fresh and dry weights was taken as the amount of water present and was converted to percentage. The crude protein was analyzed by the Kjeldahl method to determine nitrogen content, using 6.25 as the conversion factor to get crude protein from total nitrogen (WANG et al., 2008). Ash content was determined by using samples (pre-dried) from the analysis of moisture content analysis was heated in a furnace at $650{ }^{\circ} \mathrm{C}$ for $4 \mathrm{~h}$. The final weight was subtracted from the initial weight and converted to percentage to give an estimate of the ash content.

\section{Fourier transform infrared spectroscopy (FTIR) of glucosamine hydrochloride}

FTIR spectra of glucosamine hydrochloride from two chitin groups was analyzed using Omnic 6.0 sofware (Thermo-Nicolet, Madison, Wisconsin). The spectra was recorded using Bruker Optics ALPHA FT-IR spectrometer with spectra wavenumber from 4000 to $500 \mathrm{~cm}^{-1}$.

\section{Yield of extracted glucosamine hydrochloride} ( $\mathrm{G}-\mathrm{HCl})$

The yield of $\mathrm{G}-\mathrm{HCl}$ was determined using the following equation:

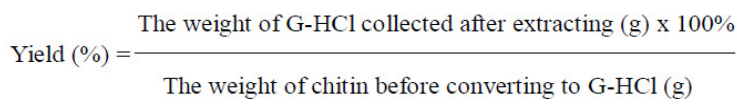

\section{Solubility of $\mathrm{G}-\mathrm{HCl}$}

For solubility checking, $1 \mathrm{~g}$ G-HCl was dissolved in $100 \mathrm{ml}$ of distilled water at ambient temperature for $2 \mathrm{~h}$ with stirring. The solution was filtered through a pre-weighed Whatman No. 1 filter paper. After removing of all the solvent, the filter paper was dried at ambient temperature and reweighed. The percent solubility was calculated from the ratio of weight gain of filter paper $\mathrm{x} 100$. 


\section{Statistical analysis}

All experiments were repeated triplicate. All data were shown as standard deviation of the mean (S.D.M). All data were analyzed by using SPSS software (SPSS 16.0 for Windows) and using Duncan's multiple range tests for evaluating differences between variables.

\section{RESULTS AND DISCUSSION}

Proximate composition of white leg shrimp shells and chitin

The proximate composition of white leg shrimp shells and black tiger shrimp shells are shown in table 1 . The percentage of protein in white leg shrimp shells and black tiger shrimp shells was $49.43 \pm 0.45$ and $49.51 \pm 0.54$, respectively while the ash content in these shells was $25.32 \pm 0.24$ and $28.37 \pm 0.35$, respectively. The high amount of protein found in white leg shrimp shells and black tiger shrimp shells, was similar to that in shrimp waste (SHAHIDI, 1994).

Similar to common method, for the production of crude chitin, shrimp shells were soaked in acidic solution and continuously in alkaline solution to remove ash and protein content, respectively. Shrimp shells after treating with $\mathrm{HCl} 6 \%$ for $12 \mathrm{~h}$ effectively removed the ash content (from 25.32 to $0.87 \%$ in white leg shrimp shells and from 28.37 to $0.89 \%$ in black tiger shrimp shells). All shrimp shells showed the ash content less than $1 \%$ after demineralization in $\mathrm{HCl}$, it is the important condition to produce high quality chitin (NO \& MAYER, 1995).

For removing protein content, samples after demineralization were separated into 2 groups; first group soaked in alkaline solution $(\mathrm{NaOH}$ $8 \%$ for $36 \mathrm{~h}$ ) and second group treated in enzyme solution (enzyme Alcalase $0.2 \%$ for $36 \mathrm{~h}$ ). The effectiveness of removing protein in first group by using traditional method (alkaline method) could be observed in table 2 (the protein in white leg shrimp shells reduced from 49.43 to $3.26 \%$ and decreased from 49.57 to $3.43 \%$ in black tiger shrimp shells).
With purpose of reducing the chemical waste in environment, second group replaced for $\mathrm{NaOH}$ $8 \%$ by enzyme Alcalase $0.2 \%$ was also shown the ability of reducing protein in shrimp shells (from 49.43 to $4.12 \%$ in white white leg shrimp shells and from 49.57 to $4.29 \%$ in black tiger shrimp shells).

\section{Extraction yield of $\mathrm{G}-\mathrm{HCl}$ from chitin}

Extraction yields of $\mathrm{G}-\mathrm{HCl}$ from two types of shrimp shells chitin, which were removed protein by alkaline method and enzyme method, are presented in table 3. The $\mathrm{G}-\mathrm{HCl}$ yield from white leg shrimp shells chitin using alkaline solution to remove protein $(60.31 \pm 2.06 \%)$ was slightly higher than that from black tiger shrimp shells chitin $(57.32 \pm 1.79 \%)$. The similar tendency could be observed in chitin treated in enzyme Alcalase, which had higher yield in white leg shrimp shells chitin $(58.64 \pm 1.82 \%)$ when compared to black tiger shrimp shells chitin $(57.07 \pm 2.02 \%)$. The yield of $\mathrm{G}-\mathrm{HCl}$ depends on extracted temperature and the ratio of chitin/ $\mathrm{HCl}$ solution (w/v). The increase of extracted temperature leads to faster dissolvability of chitin and this can contribute to a more effective hydrolysis (BENAVENTE et al., 2015). The extraction yield of G-HCl from shrimp shells $(57.07-60.31 \%)$ was similar to yield of extracted $\mathrm{G}-\mathrm{HCl}$ from crustacean shells (58\%) (BENAVENTE et al., 2015) but lower than yield of $\mathrm{G}-\mathrm{HCl}$ from tiger prawn waste $(65.33 \%)$ and Persian Gulf shrimp (87.3\%) (EKO et al., 2014; MOJARRAD et al., 2007). In present study, there was no significant difference between the extraction yields of $\mathrm{G}-\mathrm{HCl}$ from two types of shrimp shells chitin in the similar conditions of temperature and ratio of chitin/ $\mathrm{HCl}$ solution.

\section{Solubility of $\mathrm{G}-\mathrm{HCl}$}

The solubility of the glucosamine produced from two types of chitin in water at room temperature can be seen in table 4 . The tests of glucosamine hydrochloride solubility were carried out using water at room temperature. The solubility

Table 1 - The chemical compositions of shrimp shells.

\begin{tabular}{|c|c|c|c|}
\hline \multirow{2}{*}{ Sample } & \multicolumn{3}{|c|}{ 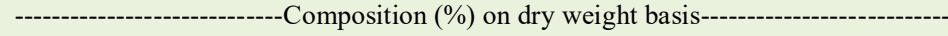 } \\
\hline & Moisture content & Ash content & Protein content \\
\hline White leg shrimp shells & $6.21 \pm 0.22$ & $25.32 \pm 0.24$ & $49.43 \pm 0.45$ \\
\hline Black tiger shrimp shells & $5.25 \pm 0.17$ & $28.37 \pm 0.35$ & $49.51 \pm 0.54$ \\
\hline
\end{tabular}

Data are expressed as mean \pm standard deviation $(n=3)$. 
Table 2 - The proximate compositions of crude chitin from shrimp shells.

\begin{tabular}{|c|c|c|c|c|}
\hline \multirow{2}{*}{ Deproteinization method } & \multicolumn{2}{|c|}{-------Chitin from white leg shrimp shells-------- } & \multicolumn{2}{|c|}{-----Chitin from black tiger shrimp shells---- } \\
\hline & Ash content $(\%)$ & Protein content $(\%)$ & Ash content $(\%)$ & Protein content $(\%)$ \\
\hline Deproteinization by alkaline method & $0.87 \pm 0.03$ & $3.26 \pm 0.04$ & $0.89 \pm 0.08$ & $3.43 \pm 0.06$ \\
\hline Deproteinzation by enzyme method & $0.87 \pm 0.03$ & $4.12 \pm 0.05$ & $0.89 \pm 0.08$ & $4.29 \pm 0.09$ \\
\hline
\end{tabular}

Data are expressed as mean \pm standard deviation $(\mathrm{n}=3)$.

of $\mathrm{G}-\mathrm{HCl}$ produce removed protein content by alkaline method and enzyme method was 87.71 and $84.07 \%$ in white leg shrimp shells chitin and 84.67 and $82.59 \%$ in black tiger shrimp shells chitin, respectively. It can be explained that this process not only removes the acetyl group but also splits up the chitosan polymer into shorter units. As a result, the chloride ions (Cl-) from the hydrochloric acid $\mathrm{HCl}$ can easily to bind with the chitosan amine groups in the formation of $\mathrm{NH}_{3} \mathrm{Cl}$. The hydroxyl bond between $\mathrm{O}-\mathrm{H}$ and $\mathrm{NH}_{3} \mathrm{Cl}$ makes glucosamine hydrochloride readily soluble in water (EKO et al., 2014). Furthermore, KRALOVEC \& BARROW (2008) reported that solubility increases or decreases with the temperature of the solvent and that glucosamine can easily be dissolved in water at a temperature of $20^{\circ} \mathrm{C}$. If a substance can be readily dissolved at low temperatures, this indicates that it is highly soluble. Overall, the deproteinization method was not affected the solubility of $\mathrm{G}-\mathrm{HCl}$ from shrimp shells.

Fourier transform infrared spectroscopy (FTIR) of G- $\mathrm{HCl}$

Figure 1 shows the FTIR spectra of glucosamine hydrochloride extracted from two types of chitin removed protein by alkaline method and by enzyme method. The FTIR spectra of G-HCl from both types of chitin indicated an extremely high degree of similarity with $\mathrm{G}-\mathrm{HCl}$ commercial reference, which are essentially identical with regard to the band-positions of G-HCl main groups. The FTIR spectrum of $\mathrm{G}-\mathrm{HCl}$ produced from white leg shrimp shells (deproteinization by $\mathrm{NaOH}$ and enzyme Alcalase) appeared at 3290.4 and $3289.67 \mathrm{~cm}^{-1}$ in association with the $\mathrm{O}-\mathrm{H}$ and $\mathrm{N}-\mathrm{H}$ stretching (BRUGNEROTTO et al., 2001), and from a $\mathrm{NH}_{2}$ scissoring band at 1616.39 and $1615.98 \mathrm{~cm}^{-1}$ and at 1096.56 and $1094.37 \mathrm{~cm}^{-1}$ due to secondary alcohol $-\mathrm{OH}$. The data of FTIR analysis in G-HCl from black tiger shrimp shells showed the similar wavelength number at 3293.37 and $3292.08 \mathrm{~cm}^{-1}$, at 1618.93 and $1618.41 \mathrm{~cm}^{-1}$ and at 1095.06 and 1094.31 $\mathrm{cm}^{-1}$, respectively for two group samples removed protein by two different methods. In agreement with this result, the study of BENAVENTE et al. (2015) and EKO et al. (2014), reported that the FTIR spectra of G-HCl made from crustacean shells and Persian Gulf shrimp was similar to standard glucosamine with wavelength number of 3370-3300, 1615 and 1094 $\mathrm{cm}^{-1}$, respectively. The similar in wavelength number between $\mathrm{G}-\mathrm{HCl}$ from shell of white leg shrimp, black tiger shrimp and crustacean shells, Persian Gulf shrimp in research of BENAVENTE et al. (2015) and EKO et al. (2014) are considered normal and acceptable as long as the values are still within the wavelength ranges for each functional group.

\section{CONCLUSION}

Glucosamine hydrochloride could be extracted from the white leg shrimp shells and black tiger

Table 3 - The extraction yields of $\mathrm{G}-\mathrm{HCl}$ from two types of chitin

\begin{tabular}{lcc}
\hline Sample & & \\
& Deproteinization by using alkaline & Deproteinization by using enzyme Alcalase \\
\hline Chitin from white leg shrimp shells & $60.31 \pm 2.06^{\mathrm{a}}$ & $58.64 \pm 1.82^{\mathrm{a}}$ \\
Chitin from black tiger shrimp shells & $57.32 \pm 1.79^{\mathrm{a}}$ & $57.07 \pm 2.02^{\mathrm{a}}$ \\
\hline
\end{tabular}

Data are expressed as mean \pm standard deviation $(n=3)$.

Different superscripts in the same column indicate statistical differences $(P<0.05)$. 
Table 4 - The solubility of G-HCl from two types of chitin.

\begin{tabular}{lcc}
\hline Sample & Deproteinization by using enzyme Alcalase \\
\hline Chitin from white leg shrimp shells & Deproteinization by using alkaline & $84.07 \pm 2.16^{\mathrm{a}}$ \\
Chitin from black tiger shrimp shells & $87.71 \pm 1.69^{\mathrm{a}}$ & $82.59 \pm 1.77^{\mathrm{a}}$ \\
\hline
\end{tabular}

Data are expressed as mean \pm standard deviation $(n=3)$.

Different superscripts in the same column indicate statistical differences $(P<0.05)$.

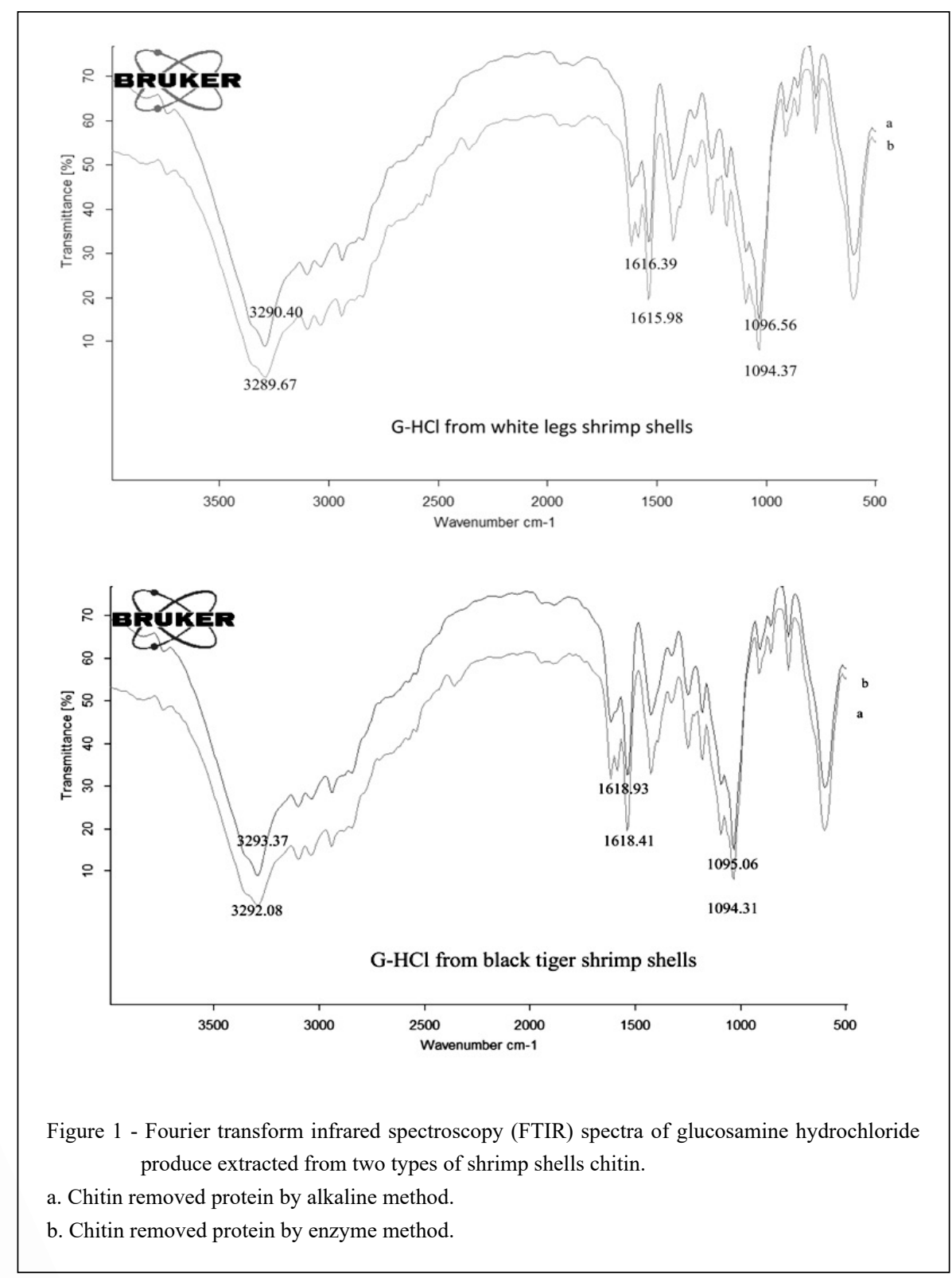

Ciência Rural, v.52, n.1, 2022. 
shrimp shells by different methods to remove protein content. The results of extraction yield, the solubility and FTIR spectrum showed no significantly difference between glucosamine hydrochloride produced from chitin removed protein by alkaline and enzyme method. These results suggest that glucosamine hydrochloride could be effectively obtained from the processing by-products of some commercial shrimp species from Vietnam, and using enzyme method of removing protein to have potential as a realistic alternative to alkaline method.

\section{ACKNOWLEDGEMENTS}

This study is funded in part by the Can Tho University Improvement Project VN14-P6, supported by a Japanese ODA loan.

\section{DECLARATION OF CONFLICT OF INTEREST}

The authors declare no conflict of interest. The founding sponsors had no role in the design of the study; in the collection, analyses, or interpretation of data; in the writing of the manuscript, and in the decision to publish the results.

\section{AUTHORS' CONTRIBUTIONS}

All authors contributed equally for the conception and writing of the manuscript. All authors critically revised the manuscript and approved of the final version.

\section{REFERENCES}

AOAC (2000). Official methods of analysis. Arlington: Association of Official Analytical Chemists Inc.

ANDERSON, J.W. et al. Glucosamine effects in humans: a review of effects on glucose metabolism, side effects, safety considerations and efficacy. Food and Chemical Toxicology, v.43, p.187-201, 2005. Available from: <https://europepmc.org/article/med/15621331>. Accessed: Apr. 20, 2020. doi: 10.1016/j.fct.2004.11.006 .

BENAVENTE, M. et al. Production of glucosamine hydrochloride from crustacean shell. Journal of Pharmacy and Pharmacology, v.3, n.1, P.20-26, 2015. Available from: <https://www. researchgate.net/publication/282352194>. Accessed: Apr. 20, 2020. doi: 10.17265/2328-2150/2015.01.003.

BRUGNEROTTO, J. et al. An infrared investigation in relation with chitin and chitosan characterization. Polymer, v.42, n.8, p.35693580, 2001. Available from: <https://www.researchgate.net/ publication/216284055>. Accessed: Apr. 10, 2020. doi: 10.1016/ S0032-3861(00)00713-8.

EKO, C., et al. Development of a pressurized hydrolysis method for producing glucosamine. Asian Journal of Agriculture and Food Science, v.2, n.5, p.390-396, 2014. Available from: $<$ https://ajouronline. com/index.php/AJAFS/article/view/1641>. Accessed: Apr. 20, 2020.

HOUPT, J.B. et al. Effect of glucosamine hydrochloride in the treatment of pain of osteoarthritis of the knee. The Jounal of Rheumatology, v.26, p.2423-2430, 1999. Available from: <https://pubmed.ncbi.nlm. nih.gov/10555905/>. Accessed: Apr. 20, 2020. PMID: 10555905.

JORGE, M.M. et al. Sustainable production with obtaining glucosamine from crab exoskeletons. Ciência Rural, v.49, n.9, p.1-10, 2019. Available from: <https://www. scielo.br/scielo.php? script $=$ sci arttext\&pid=S0103$84782019000900752 \& t \operatorname{lng}=\mathrm{en}>$. Accessed: Apr. 20, 2020. doi. org/10.1590/0103-8478cr20190021.

KRALOVEC, A; BARROW, C.J. Glucosamine production and health benefits. In: Barrow C, Shahidi F, editors. Marine Nutraceuticals and Functional Foods. Boca Raton (FL): CRC Press, Florida, USA, 2008. p.198-227.

LEITE, A. et al. Optimization of synthesis, physical and chemical analysis and use in an experimental model of glucosamine hydrochloride and glucosamine. In: VI Northeast Regional Meeting SBBQ, Fortaleza, Brazil, 2002.

LI, J. et al. Optimization of preparation process of glucosamine hydrochloride. Anhui Medical and Pharmaceutical Journal, v.11, n.1, p.11-12, 2007. Available from: <http://en.cnki.com.cn/Article_en/ CJFDTotal-AHYY200701 005.htm>. Accessed: Apr. 30, 2018.

LUO, J. et al. Effect of glucosamine hydrochloride in ameliorating knee osteoarthritis. Chinese Journal of Clinical Rehabilitation, v.9, p.70-72, 2005. Available from: <https://www.ncbi.nlm.nih. gov/pmc/articles/PMC6097075/>. Accessed: Apr. 30, 2018. doi: $10.1007 / \mathrm{s} 10067-018-4106-2$.

MOJARRAD, J.S. et al. Preparation of glucosamine from exoskeleton of shrimp and predicting production yield by response surface methodology. Journal of agricultural and food chemistry, v.55, n.6, p.2246-2250, 2007. Available from: $<$ https:// pubs.acs.org/doi/abs/10.1021/jf062983a >. Accessed: Apr. 30, 2018. doi: 10.1021/jf062983a.

NO, H.K; MEYER, S.P. Preparation and characterization of chitin and chitosan: a review. Journal of Aquatic Food Products Technology, v.4, p.27-52, 1995. Available from: <https://www. tandfonline.com/doi/abs/10.1300/J030v04n02 03>. Accessed: Apr. 30, 2018. doi.org/10.1300/J030v04n02_03.

SHAHIDI, F. Seafood processing by-products. In: SHAHIDI, F.; BOTTA, J.R. Seafoods: Chemistry, processing, technology and quality. Blackie Academic and P rofessional, London, New York, 1994. Chap. 2, p. 320- 333.

SHAHIDI, F., et al. Food applications of chitin and chitosan. Trends in Food Science and Technology, v.10, n.2, p.37-51, 1999. Available from: <https://www.sciencedirect.com/science/ article/abs/pii/S0924224499000175>. Accessed: Apr. 30, 2018. doi.org/10.1016/S0924-2244(99)00017-5.

$\mathrm{XU}$, Y. et al. Chitin purification from shrimp wastes by microbial deproteination and decalcification. Applied Microbiology and Biotechnology, v.79, p.687-697, 2008. Available from: <https:// pubmed.ncbi.nlm.nih.gov/18418590/>. Accessed: Apr. 30, 2018. doi. 10.1007/s00253-008-1471-9.

WANG, L. et al.. Isolation and characterisation of collagen from the skin, scale and bone of deep - sea redfish (Sebastes mentella). Food Chemistry, v.108, p.616-623, 2008. Available from: $<$ https://pubmed.ncbi.nlm.nih.gov/26059140/>. Accessed: Apr. 24, 2018. 